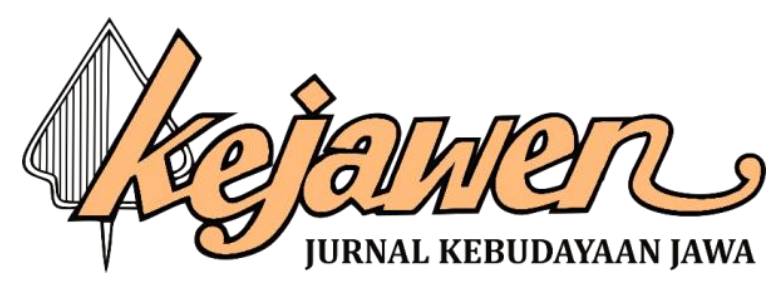

\title{
RELEVANSI NILAI MORAL RELIGIUSITAS SERAT YUSUF TERHADAP ERA DISRUPTIF
}

\author{
Fita Dwi Anjarwati, Respati Retno Utami \\ Universitas Negeri Surabaya \\ fita.18005@mhs.unesa.ac.id, respatiutami@unesa.ac.id
}

\begin{abstract}
Abstrak
Penelitian ini bertujuan untuk menganalisis dan mendeskripsikan nilai moral religiusitas serta relevansi nilai moral religiusitas terhadap era disruptif. Penelitian ini termasuk penelitian kualitatif. Metode yang digunakan dalam penelitian ini ada dua yaitu metode analisis-deskriptif dan metode wawancara. Metode analisis-deskriptif digunakan untuk menganalisis dan mendeskripsikan data yang mengandung nilai moral religiusitas berupa kata-kata, frasa, klausa, dan kalimat dalam Serat Yusuf. Metode wawancara digunakan untuk menggali lebih dalam pengetahuan nilai moral religiusitas dalam Serat Yusuf. Pendekatan yang digunakan adalah pendekatan objektif. Pendekatan objektif memberikan perhatian pada karya sastra sebagai sebuah pendekatan yang menitikberatkan pada karya sastra atau teks. Sumber data dari penelitian ini adalah Serat Yusuf yang terdiri atas 12 pupuh dengan 4 jenis pupuh. Teknik pengumpulan data yang digunakan dalam penelitian ini yaitu dengan teknik inventarisasi naskah, deskripsi naskah, dan transliterasi. Dari hasil penelitian diketahui terdapat tiga nilai moral religiusitas: (1) keimanan terhadap Tuhan, (2) ketaatan terhadap Tuhan dan (3) kepasrahan terhadap Tuhan. Selain itu, hasil penelitian ini menghasilkan relevansi nilai moral religiusitas dalam Serat Yusuf terhadap era disruptif.
\end{abstract}

Kata kunci: nilai moral, religi, era disruptif

\section{RELEVANCE OF MORAL VALUE RELIGIUSITY OF JUSUF'S TEXT TO DISRUPTIVE ERAS}

\begin{abstract}
The purpose of this study was to analyze and describe the moral values of religiosity and the relevance of the moral values of religiosity to the disruptive era. This research is a qualitative research. There are two methods used in this research, namely the analysisdescriptive method and the interview method. Descriptive analysis method is used to analyze and describe data that contains moral values of religiosity in the form of words, phrases, clauses, and sentences in Yusuf's Manuscripts. The interview method is used to dig deeper knowledge of the moral values of religiosity in Yusuf's Manuscripts. The approach used is an objective approach. The objective approach pays attention to literary works as an approach that focuses on literary works or texts. The data source of this study is the Yusuf Manuscript which consists of 12 stanzas with 4 stanzas. The data collection techniques used in this study were manuscript inventory, manuscript description, and transliteration techniques. From the research results, it is known that there are three moral values of religiosity: (1) faith in God, (2) obedience to God and (3) submission to God. In addition, the results of this study produce the relevance of the moral values of religiosity in Yusuf's Manuscripts to the disruptive era.
\end{abstract}

Keywords: moral values, religion, disruptive era 



\section{PENDAHULUAN}

Serat Yusuf merupakan naskah yang masuk pada abad ke-15 sampai 16 Masehi sehingga naskah tersebut digolongkan dalam sastra Jawa baru berbentuk tembang. Serat Yusuftersebut telah dijelaskan dalam beberapa katalog agar memudahkan peneliti memilih naskah yang cocok berdasarkan pertimbangan yang ada. Studi katalog yang dilakukan dalam penelitian ini melalui katalog Museum Radyapustaka, Katalog Behrend, dan juga wawancara terhadap pengelola museum Mpu Tantular.

Berdasarkan studi katalog yang telah dilakukan dapat ditentukan satu naskah yaitu Serat Yusuf versi aksara pegon Jawa yang dapat ditemukan di museum Mpu Tantular. Terpilihnya naskah tersebut dikarenakan paling lengkap dengan keadaan yang baik untuk diteliti. Serat Yusuf memiliki ajaran didaktis berupa nilai moralis dan religiusitas yang bermanfaat bagi manusia dengan ditandai dengan banyak ditemukan berbagai macam ajaran Ketuhanan untuk menggambarkan kewajiban manusia kepada Sang Pencipta. Serat Yusuf mengandung nilai moral religiusitas yang menarik untuk diterapkan di era disruptif. Selain itu belum banyak penelitian yang membahas nilai moral religiusitas Nabi Yusuf. Maka dari itu penelitian mengenai nilai moral religiusitas ini menarik untuk menjadi fokus penelitian.

Kajian komprehensif dari Serat Yusuf yang sejenis telah dilakukan sebelumnya oleh Estriana D.P. dengan mengangkat judul Sejarah Manuskrip Lontar Yusuf sebagai Media Dakwah Masyarakat Osing Banyuwangi pada tahun 2017 sebagai bahan skripsi. Penelitian ini juga bersumber dari penelitian yang telah dilakukan sebelumnya oleh Martina Pupita R. dengan mengangkat judul Nilai Religiositas dalam Lontar Yusuf dan Relevansinya di Era Disruptif pada tahun 2020 sebagai artikel.

Fenomena Islam di tanah Jawa tidak semurni Negara Arab dalam menjalankan ibadahnya (Endraswara, 2018:70). Akan tetapi, masuknya Islam di tanah Jawa dipelopori oleh paham mistik kejawen. Mistik kejawen merupakan paham yang berkembang karena adanya aliran kebatinan di wilayah Jawa. Pada saat itu, beragam asumsi masyarakat yang muncul seiring dengan masuknya agama Islam ini. Berbagai tradisi turun-temurun yang berasal dari nenek moyang dianggap syirik (menyekutukan Tuhan). Jika diteruskan secara demikian, maka dapat dipastikan bahwa agama Islam akan ditolak keberadaannya dalam masyarakat Jawa. Oleh sebab itu, para ulama bahkan wali memanfaatkan seni tradisi yang sangat popular di tanah Jawa sebagai salah satu upaya menyebarkan agama Islam, salah satunya melalui media tembang dari naskah lama.

Ajaran-ajaran nilai moral religius (tasawuf) disampaikan melalui tembang. Dengan adanya ajaran tasawuf, agama Islam yang diajarkan memiliki persamaan pikiran yang sebelumnya bercorak Hindu sehingga lebih mudah diterima. Melalui perantara tembang tersebut, ulama dan wali menyarankan agar dakwah Islam digambarkan seperti menabur bunga yang harum. Sehingga membawa kesenangan, kegembiraan serta lebih enak didengar. Jika menggunakan dakwah yang terbilang kasar sampai melukai perasaan orang lain harus dihindari. Dengan penggunaan metode dakwah tersebut, masyarakat enggan mempelajari agama Islam. Nilai moral diartikan sebagai ukuran baik-buruknya seseorang, baik sebagai pribadi maupun warga dalam masyarakat dan negara. Sehubungan dengan pemikiran tersebut, Aristoteles (Hidayat, 2015:25) mengatakan bahwa manusia adalah animal seducandum, yaitu binatang yang wajib dan dapat dididik. Seseorang atau masyarakat yang tidak memperhatikan pentingnya good habits (kebiasaan baik) akan menjadi individu yang terbiasa dengan hal-hal buruk. Oleh sebab itu, pengembangan nilai moral dalam seseorang atau masyarakat menjadi sangat penting dan diharapkan mampu membentuk karakter bangsa bermoral dan bermartabat. Sedangkan nilai religiusitas didefinisikan dalam beberapa istilah yang memiliki hubungan satu sama lain, yaitu religi. Religi merupakan kata benda yang didefinisikan kepercayaan kepada Tuhan, kepercayaan kekuatan adikodrati diatas manusia, kepercayaan animisme-dinamisme dan agama. Dari penjelasan tersebut dapat diketahui bahwa nilai religiusitas dalam diri manusia berperan dalam pengembangan karakter manusia itu sendiri. Sehingga ajaran religi atau agama yang bersifat positif akan diimplementasikan dalam 
kehidupan. Wujud paling penting dari nilai religiusitas adalah manusia dapat merasakan secara batin dengan Tuhan beserta komponen agama, misalnya aqidah, syari'ah, dan akhlak di dalam perubahan zaman yang pesat ini.

Arus perubahan zaman tidak hanya melakukan sharing of information, akan tetapi juga menyebabkan bergesernya identitas budaya yang kemudian menjadi suatu ancaman tradisi lokal, nilai lokalitas etnik dan warisan adat para leluhur (Pora, 2014:113). Hal tersebut juga dapat menjadi ancaman untuk Naskah Serat Yusuf. Penyebaran teknologi informasi yang sangat cepat dan mudah tidak jarang menimbulkan kemungkinan pemanfaatan dalam bidang yang menyimpang. Di negara manapun kondisi sosial semakin lama akan semakin memburuk, kejahatan-kajahatan sosial akan menciptakan ketidaknyamanan dalam hidup (Ohoitimur, 2018:146). Selain itu, dampak yang mungkin muncul dapat berupa kekerabatan sebagai institusi sosial akan tergeser keberadaannya, sementara indeks angka perceraian semakin meningkat, kualitas dalam dunia pendidikan akan menurun, kelahiran anak yang belum direncanakan bertambah serta hilangnya kepercayaan sesama dalam kehidupan. Berbagai macam dampak tersebut merupakan indikator telah munculnya dua gangguan serius dalam era disruptif.

Di era disruptif ini, Bangsa Indonesia sedang mengalami dekadensi moral yang terjadi hampir pada semua bidang kehidupan dan lapisan masyarakat. Hampir seluruh lapisan masyarakat memiliki tatanan tersendiri, bahkan komunitas terkecil dalam masyarakat memiliki moral dengan sistemnya sendiri. Kenyataan lain terdapat pada generasi muda yang jarang sekali mempelajari lebih dalam Naskah tua. Minimnya kesadaran dari generasi muda menjadi salah satu faktor penyebab tergerusnya nilai-nilai moral religiusitas di era disruptif. Padahal kelestarian sebuah warisan budaya bergantung besar pada generasi muda. Ohoitimur (2018:145) mengungkapkan bahwa era disruptif dijelaskan sebagai gangguan. Artinya, masyarakat yang dikondisikan oleh kekuatan informasi akan cenderung lebih menghargai nilai-nilai yang dijunjung tinggi dalam suatu demokrasi. Yaitu kebebasan dan kesetaraan yang seimbang. Namun disamping itu juga muncul berbagai macam kejahatan dan pergeseran tatanan sosial dalam masyarakat.

Berdasarkan latar belakang penelitian diatas, maka rumusan masalah penelitian ini adalah 1) apa saja nilai moral religiusitas yang terkandung dalam Serat Yusuf, dan 2) bagaimana relevansi nilai moral religiusitas dalam Serat Yusuf terhadap era disruptif. Dari rumusan masalah tersebut, maka tujuan dari penelitian ini adalah 1) mengetahui nilai moral religiusitas yang terkandung dalam Serat Yusuf, dan 2) mengetahui relevansi nilai moral religiusitas terhadap era disruptif. Adapun beberapa hal penting yang mendasari peneliti melakukan penelitian terhadap Serat Yusuf adalah sebagai bagian dari warisan budaya di masa lampau, khusunya pada masa Islamisasi Jawa serta keterasingan terhadap karya sastra lama, karena Serat Yusuf menggunakan huruf pegon yang menyulitkan pembaca. Penelitian ini juga diharapkan dapat memberikan sumbangsih terhadap ilmu filologi dan diharapkan juga dapat dijadikan bahan pembelajaran bahasa Jawa di sekolah khususnya bidang nilai moral religiusitas. Penelitian ini juga diharapkan memberikan tambahan pengetahuan mengenai nilai moral religiusitas di era disruptif bagi pembaca.

Teori yang digunakan dalam penelitian ini adalah filologi dan sastra. Menurut pendapat Djamaris (dalam Ulfah, 2011:18) istilah filologi berasal dari bahasa latin yang terdiri dari dua kata, yaitu philos dan logos. Philos dimaknai dengan cinta sedangkan logos dimaknai sebagai ilmu. Jadi filologi merupakan rasa cinta terhadap kata dan ilmu. Ilmu yang dimaksud dalam kajian filologi adalah naskah. Didalam naskah terdapat teks yang menyimpan beraneka macam ilmu kebudayaan masa lampau. Filologi merupakan ilmu yang berhubungan dengan studi teks yang dilakukan untuk mengungkap hasil budaya masa lampau berupa karya tulisan. Dengan adanya teori filologi dapat digunakan untuk meneliti Naskah Yusuf sehingga menghasilkan suntingan dan transliterasi teks dengan tujuan untuk mengetahui isi dari teks.

Dengan adanya tulisan ini merupakan salah satu upaya untuk mengkaji dan mempertahankan nilai-nilai moral religiusitas yang terdapat dalam Serat Yusuf beraksara pegon Jawa. Upaya tersebut dilakukan dengan tujuan untuk melestarikan kandungan Naskah sehingga 
bisa disebarluaskan kepada masyarakat. Sebab nilai-nilai dalam Serat Yusuf memiliki sifat yang adiluhung yang mampu diimplementasikan dalam kehidupan sehari-hari khususnya di era desruptif. Perbedaan penelitian ini dengan penelitian sebelumnya terletak pada permasalahan yang diangkat hanya satu dan pemaparan data yang kurang rinci.

\section{METODE}

Metode yang digunakan dalam penelitian ini ada dua jenis yaitu metode deskriptif-analisis konten dan wawancara. Metode deskriptif-analisis konten merupakan salah satu metode yang berfungsi untuk mendeskripsikan, memberikan gambaran, atau menganalisis suatu hasil penelitian melalui sampel atau data yang telah terkumpul tetapi tidak digunakan untuk membuat kesimpulan yang lebih luas (Sugiyono, 2017:147). Dalam metode tersebut, analisis deskriptif merupakan teknik analisis data yang mendeskripsikan data secara apa adanya sehingga dapat menimbulkan kemudahan dengan jelas bagi pembaca. Sementara analisis isi berusaha menganalisis dokumen untuk mengetahui isi dan makna Serat Yusuf. Metode wawancara digunakan untuk menggali informasi atau ide dengan cara tanya jawab, sehingga permasalahan dapat dikerucutkan menjadi topik tertentu (Sugiyono, 2015:72). Penggunaan metode wawancara dalam pengkajian Serat Yusuf bertujuan untuk memenimalisir waktu dan informasi yang diperoleh akan lebih akurat, komprehensif juga jujur. Metode wawancara digunakan untuk melengkapi data yang dirasa kurang dari metode sebelumnya. Teknik wawancara yang digunakan dalam penelitian adalah wawancara terstruktur, yang mana interview dilakukan berdasarkan daftar pertanyaan yang telah disiapkan oleh peneliti. Pertanyaan dalam metode wawancara yang dilakukan dalam pengkajian Naskah Yusuf berupa (1) nilai moral religiusitas yang terkandung dalam Serat Yusuf dan (2) ringkasan keseluruhan isi dari Serat Yusuf menurut narasumber. Naskah Serat Yusuf tersebut berasal dari Museum Mpu Tantular dengan nomor inventaris 07.208 atau N.F.0519/34 serta panjang $22 \mathrm{~cm}$, lebar $16 \mathrm{~cm}$ dan tebal 3. Naskah Serat Yusuf ini terdiri atas 12 pupuh dengan 4 jenis pupuh. Naskah tersebut terdiri dari tembang asmarandana, durma, sinom dan pangkur.

Teknik Pengumpulan Data merupakan cara yang harus dilakukan agar menghasilkan data yang mendukung penelitian Serat Yusuf (Sugiyono, 2017:224). Tahap pengumpulan data dalam penelitian ini terdiri dari tiga cara, yaitu teknik inventarisasi naskah, deskripsi naskah, serta transliterasi. Teknik inventarisasi naskah merupakan teknik yang bertujuan untuk mencari dan mencatat semua naskah yang sama judul atau isinya dengan naskah yang akan diteteliti (Sudardi, 2001:29). Deskripsi naskah merupakan tahapan yang menghimpun data yang berhubungan dengan naskah. Adapun yang dideskripsikan menyangkut keadaan naskah, judul naskah, nomor naskah, tulisan, bahan, ukuran naskah, tebal naskah, tempat penyimpanan, asal naskah, jumlah baris perhalaman, cara tata penulisan, bahasa, bentuk teks, umur naskah, pengarang, fungsi sosial juga ikhtisar (Mulyani, 2009:8). Transliterasi merupakan tata cara penggantian jenis tulisan satu demi satu jenis tulisan kepada jenis tulisan yang lainnya (Basuki, Thohir, Abdullah, Muzakka, Yusuf, dan Rukiyah, 2004:42). Transliterasi digunakan untuk mengalihtulisan pegon jawa menjadi aksara latin tanpa mengubah artinya. Tiga tahapan tersebut harus dilakukan peneliti untuk menghasilkan naskah yang bersih agar dapat dianalisis dengan menggunakan teori lainnya.

Tahap pertama dalam analisis isi ialah reduksi data yang bertujuan untuk memilah dan meringkas data yang dibutuhkan oleh peneliti. Klasifikasi data ini dilaksanakan dengan cara memilah-milah nilai moral religiusitas yang terdapat dalam data Serat Yusuf. Nilai moral religiusitas tersebut diklasifikasikan berdasarkan tiga hal yaitu keimanan, ketaatan dan kepasrahan. Data selanjutnya disajikan dalam bentuk uraian untuk menunjukkan interpretasinya. Data yang telah disajikan selanjutnya dihubungkan dengan hasil wawancara dan keterangan dari berbagai buku yang berhubungan dengan era disruptif. Narasumber yang dipilih adalah orang-orang yang ahli dengan cerita Serat Yusuf, baik dari segi naskah asli maupun Al-Quran dan Hadist. 


\section{HASIL DAN PEMBAHASAN}

\section{Nilai Moral Religiusitas}

Moralitas merupakan sebuah kata yang diambil dari bahasa Latin mos (mores, jamak) yang diartikan sebagai adat istiadat, kebiasaan nilai-nilai atau tata cara kehidupan. Sehubungan dengan hal tersebut, Nurgiyantoro (2013:429-430) mengungkapkan bahwa makna moral yang sesungguhnya adalah kebiasaan serta adat dalam berperilaku masih dikendalikan oleh konsepkonsep yang di dalamnya memuat peraturan dan telah menjadi kebiasaan bagi masyarakat suatu budaya. Moralitas merupakan kualitas yang mengacu pada budi pekerti, sopan santun, benar atau salah serta baik atau buruknya perbuatan manusia. Sedangkan secara terminologi, kata moral memiliki beberapa pengertian, misalnya menurut (1) Magnis-Susino yang mengatakan bahwa moral selalu mengacu pada baik dan buruknya manusia sebagai manusia, (2) Baron yang menyatakan bahwa moral diartikan sebagai hal-hal yang berhubungan dengan larangan dan tindakan yang mengacu pada benar atau salah, dan (3) W. J. S. Poerdarminta yang berpendapat bahwa moral merupakan ajaran tentang baik dan buruknya kelakuan.

Moralitas merupakan fenomena manusiawi yang bersifat universal (Bertens, 2011:14). Artinya adalah sesuatu tentang baik dan buruk merupakan sesuatu yang biasa (umum) yang terdapat dimanapun pada segala zaman. Nilai dari moralitas dapat digunakan manusia sebagai tolok ukur untuk mengukur kebaikan dari seseorang. Sehubungan dengan hal tersebut, dapat diketahui bahwa moralitas memiliki dua arti. Pertama, sistem nilai tentang bagaimana kita hidup dengan baik sebagaimana manusia. Sistem nilai yang dimaksud berupa petuah, wejangan, peraturan, nasihat dan perintah yang diwariskan secara turun temurun melalui perantara agama atau kebudayaan tertentu. Kedua, tradisi kepercayaan dalam agama atau kebudayaan yang mengatur perilaku baik dan buruk. Nilai dari moralitas memberikan manusia aturan yang konkrit tentang bagaimana manusia harus bertindak sebagai manusia bermoral dan menghindari perilaku yang tidak baik. Dengan demikian pengertian dari moralitas dapat dipahami dengan cara mengklasifikasinya sebagai berikut: (1) moral sebagai ajaran kesusilaan yang berhubungan dengan ketentuan yang berlaku dalam masyarakat, (2) moral sebagai aturan yang akan menilai perbuatan baik atau buruknya seorang manusia, dan (3) moral sebagai gejala kejiwaan yang selalu muncul beriringan dalam bentuk perbuatan. Sedangkan dalam termonologi Islam, moral dapat diartikan sama dengan "akhlak" dan akhlak memiliki pengertian yang sama dengan budi pekerti atau kesusilaan.

Ilmu akhlak menentukan kriteria dari perbuatan yang baik dan buruknya manusia. Selain itu, ilmu akhlak juga berguna secara efektif dalam upaya membersihkan diri dalam perbuatan yang menjerumuskan pada dosa dan kemaksiatan. Jika tujuan dalam ilmu akhlak tercapai, maka dapat dipastikan manusia akan memiliki kebersihan batin yang akan menumbuhkan perbuatan terpuji serta tingginya iman dalam keagamaan. Moralitas keagamaan adalah ajaran tentang baik dan buruknya suatu akhlak atau perbuatan manusia yang berhubungan dengan Tuhan didalam suatu agama. Penjelasan tersebut menunjukkan bahwa peran agama dalam kehidupan manusia sangat penting keberadaannya. Hal tersebut dikarenakan pada dasarnya manusia selalu memiliki keinginan yang sangat esensial dalam jiwanya. Keinginan tersebut dapat berupa keinginan untuk mencari sesuatu yang berbeda dari luar dirinya dan dapat memahami hatinya.

Religiusitas adalah internalisasi nilai-nilai agama dalam diri manusia. Internalisasi dalam hal ini berkaitan dengan kepercayaan terhadap ajaran agama baik dalam hati maupun ucapan. Keperceyaan tersebut kemudian diaktualisasikan dalam perbuatan dan tingkah laku. Dengan kata lain, manusia yang memiliki tingkat religiusitas tinggi akan mencerminkan perilaku yang sesuai dengan nilai dan norma dalam masyarakat. Penjelasan tersebut diperkuat oleh pendapat Sari (2013:96) yang menjelaskan bahwa apabila individu memiliki tingkat religiusitas yang tinggi, maka semakin tinggi juga kepercayaan terhadap Tuhan mereka dan mereka cenderung melakukan apapun yang telah ditulis dan diperintahkan dalam kitab suci yang mereka yakini. Sebaliknya, apabila individu memiliki nilai religiusitas yang rendah maka akan semakin rendah juga 
kepercayaan kepada Tuhan dan kurang maksimal dalam mengamalkan perintah-Nya. Religiusitas dapat dimaknai sebagai kesatuan unsur-unsur yang komprehensif, yang menjadikan seseorang disebut beragama (being religious) bukan sekedar mempunyai agama (having religious).

Religiusitas merupakan tingkat penghayatan individu dalam usaha mendekatkan diri kepada Tuhan (Glock \& Stark dalam Jalaluddin, 2016:147). Dalam usaha mendekatkan diri tersebut, mencakup lima dimensi penting di dalamnya, yaitu (1) keyakinan/ideologi, (2) praktik agama/ritualistik, (3) pengalaman/eksperensial, (4) pengetahuan/intelektual, dan (5) pengalaman/konsekuensial. Menyambung gagasan dari Glock dan Stark, Good (2011:99) mendefinisikan nilai religiusitas sebagai pencarian terhadap devine, or nonmaterial aspects of life dan memiliki konsep sebagai tingkah laku serta keyakinan yang dihubungkan dengan agama institusi yang terkait. Selaras dengan berbagai pemaparan diatas, dapat disimpulkan bahwa nilai religiusitas merupakan tingkat penghayatan seorang manusia dalam usaha mendekatkan diri kepada Tuhannya yang mencakup lima dimensi penting. Kelima dimensi tersebut saling berhubungan, terikat, serta menentukan dalam membentuk religiusitas pada individu itu sendiri.

Salah satu karya sastra Jawa pada era Islamisasi yang mengandung nilai moral religiusitas adalah Naskah Serat Yusuf. Dalam Serat Yusuf tidak sedikit nilai moral religiusitas yang menjelaskan sikap atau perilaku Nabi Yusuf sesuai dengan tuntunan agama Islam. Setelah melakukan analisis data, penelitian ini menunjukkan bahwa terdapat tiga kelompok nilai moral religiusitas dalam Serat Yusuf, yaitu 1) keimanan manusia terhadap Tuhan, 2) ketaatan manusia terhadap Tuhan, dan 3) kepasrahan manusia terhadap Tuhan. Berikut pemaparannya.

\section{Keimanan Manusia terhadap Tuhan}

Keimanan merupakan basis, fondasi, dan inti dalam beragama. Secara praktis, beriman diartikan sebagai kesadaran manusia untuk yakin dan percaya kepada Tuhan, kepada kitab-Nya, kepada malaikat, kepada takdir dan kepada hari akhir (Mufid, 2016:8). Keimanan kepada manusia terhadap Tuhan merupakan hubungan yang semulia-mulianya antara manusia dengan sang pencipta. Oleh sebab itu, mendapatkan petunjuk sehingga menjadi orang beriman, adalah salah satu kenikmatan besar bahkan terbesar yang dimiliki oleh seorang manusia. Keimanan yang sesungguhnya merupakan suatu akidah atau kepercayaan yang memenuhi seluruh isi dari hati nurani. Beriman kepada Tuhan telah disebutkan dengan jelas dalam enam rukun iman agama Islam. Keimanan manusia dapat diwujudkan dengan wajibnya megetahui dan meyakini bahwa Allah itu Wajib Al-wujud Li Dzathi (ada karena dzat-Nya sendiri) dan Maha kuasa terhadap segala sesuatu sesuai kehendak-Nya. Keimanan kepada Allah juga dapat diwujudkan dengan mempercayai seluruh ke-Agungan yang telah kita lihat semasa di dunia. Misalnya seperti adanya dunia beserta seluruh isinya. Selaras dengan pemaparan tersebut, Fadhil (2012:4) mengemukakan bahwa keimanan seorang manusia dapat dilihat dari penerapan ajaran agama Islam dalam kesehariannya ('amaliyat yaumiyyat).

Kewajiban manusia yang utama adalah beriman kepada Allah. Dengan keimanan inilah manusia akan memperoleh martabat yang tinggi dan mulia di sisi Allah. Sehingga siapa saja yang beriman kepada Allah akan memperoleh pahala yang besar, baik di dunia maupun di akhirat (Q.S. Ali Imran:179). Berdasarkan penggalan ayat tersebut, maka jelaslah bahwa Allah telah menjanjikan pahala yang besar kepada orang yang benar-benar beriman, baik laki-laki maupun perempuan. Pahala besar yang dimaksud adalah surga, yaitu tempat di akhirat yang dipenuhi dengan kenikmatan yang kekal selama-lamanya. Eksistensi dari nilai keimanan adalah landasan utama bagi muslim dalam menentukan identitas keimanannya secara benar. Keimanan merupakan hal yang mendasar untuk menentukan keteguhan dan keyakinan seseorang dalam melaksanakan nilai ajaran Islam. Keimanan tidak hanya mampu diucapkan secara lisan, akan tetapi harus mampu mengintegrasikam di dalam kehidupan sosial masyarakat (Romli, 2012:121). dari pandangan tersebut, nilai keimanan dijadikan sebagai sebuah konsep yang mendasari keseluruhan sistem 
Pendidikan Islam. Dari nilai keimanan akan mampu menghadirkan kekuatan seseorang untuk meningkatkan wujud kesadaran menjadi pribadi orang yang beriman.

Dalam Naskah Yusuf telah dijelaskan bahwa Nabi Yusuf memiliki keimanan yang kuat terhadap Allah SWT. sebagai Tuhannya. Salah satu peristiwa yang mencerminkan Nabi Yusuf memiliki keimanan yang kuat adalah ketika para wanita mecoba merayunya, Nabi Yusuf berusaha mengendalikan dirinya dengan mengatakan bahwa dirinya lebih senang dipenjara daripada menuruti apa yang wanita itu inginkan. Maka daripada itu, Nabi Yusuf selalu menegakkan sikap mawas diri terhadap kelemahan diri sendiri. Di dalam Naskah Yusuf banyak dijelaskan wujud dari keimanan manusia terhadap Allah, berikut pemaparannya.

\begin{abstract}
Keimanan Nabi Yusuf dalam Pupuh I Kasmaran ( ${ }^{I}$ K) pada Bait ke-93 dan 94 Mêngkana malih ing benjing / ning ari kiyamat ika / ngalakoni kang tan sarèh / maksiyat linging tingkah/pinariksa ing ngastaha / tananganggo pulah ipun / lamun karya maksiyat // Irika asta nirangling / ngaku alamun duraka / pada nira matur age / lamun sira maksiyat / sagunge panggahota / sêdaya sami ngakui / kawêlèh ingawak dhawak /

Terjemahan:

Demikianlah kelak / pada saat hari kiamat / yang berlaku tiada sabar / berbuat penuh maksiat / diperiksa di alam kubur / tidak dapat mengelak / jika telah berlaku kemaksiatan // Kedua tangannya pun berkata / mengaku jika digunakan berbuat tercela / kedua kakinya pun berkata / jika digunakan berbuat kemaksiatan / segenap anggota badannya / semua akan sama bersaksi / maka dirinya langsung terhempas //
\end{abstract}

Bait ke-93 dan 94 yang dimuat dalam $\mathrm{P}^{1} \mathrm{~K}$ menjelaskan bahwa suatu saat nanti setiap makhluk hidup pasti menjumpai salah satu kekuasaan Allah, yaitu hari kiamat (hari akhir). Secara garis besar, hari kiamat diartikan sebagai peristiwa yang sangat besar dan dahsyat. Hari kiamat menggambarkan kehancuran apapun yang ada di dunia. Di hari kiamat nanti, semua makhluk ciptaan-Nya mengalami yaumul hisab. Yaumul hisab merupakan hari perhitungan setelah manusia dibangkitkan dari kematian (Q.S. Shad:53). Di hari itu nasib manusia akan ditentukan. dan anggota tubuh akan memberikan saksi kepada Allah atas perbuatan semasa hidup. Pada saat itu, semua manusia tidak akan bisa mengelak atas apa yang dilakukan semasa hidupnya di dunia. Penjelasan tersebut dapat diperkuat dengan pendapat Cholil (2014:312) yang mengatakan bahwa pada saat Yaumul Hisab, lidah, tangan, dan kaki akan menjadi saksi atas perbuatan yang mereka kerjakan baik perbuatan yang baik maupun perbuatan yang tercela.

Percaya pada hari kiamat termasuk dalam salah satu wujud beriman kepada Allah. Hal tersebut berhubungan dengan pendapat Thoyyibah (2016:18) yang menjelaskan bahwa orang beriman memiliki perilaku baik (mahmudah) dan meneladani amal shalih. Mengimani hari kiamat sejatinya membawa manfaat yang besar bagi manusia. Seperti yang dijelaskan oleh Nurlailah (2011:44) manfaat dari mengimani hari akhir dapat menambah keyakinan bahwa segala perbuatan di dunia merupakan bekal untuk kehidupan di akhirat, menumbuhkan sifat ikhlas dalam beramal, istiqamah, khusyu' dalam ibadahnya dan melaksanakan amar ma'ruf dan nahi munkar untuk mendapatkan keridhoan dari Allah.

\title{
Keimanan Malik (pedagang) dalam Pupuh III Kasmaran ( P III $^{\mathrm{II}}$ ) pada Bait ke-18-21
}

Diceritakan dalam Naskah Yusuf bahwa tokoh Malik merupakan seorang pedagang yang menemukan Nabi Yusuf di sebuah telaga. Peristiwa pembuangan Nabi Yusuf telah tercantum di dalam Q.S. Yusuf (8) yang berisi "Sesungguhnya Yusuf dan saudara kandungnya (Bunyamin) lebih dicintai oleh ayah (Nabi Yaqub) daripada kita sendiri, padahal kita adalah salah satu 
golongan (yang kuat). Sesungguhnya ayah kita (Nabi Ya'qub) dalam kekeliruan yang jelas." Arti dari sepenggal ayat tersebut menggambarkan alasan dibungnya Nabi Yusuf ke telaga oleh saudaranya sendiri. Telaga tersebut merupakan tempat para musafir untuk bersinggah setelah perjalanan. Ketika sampai di telaga, Malik melihat burung-burung mengitaru telaga seperti orang yang yang mengitari Ka'bah dalam haji. Ternyata burung-burung tersebut adalah jelmaan malaikat yang sedang menemani Nabi yusuf. Akhirnya, Malik memeriksa ke dalam sumur yang memiliki wangi semerbak.

Wujud keimanan yang digambarkan oleh tokoh Malik terletak pada sikapnya yang percaya bahwa Allah akan senantiasa memberikan petunjuk pada hamba-Nya yang beriman. Allah pun menolong Nabi Yusuf dengan mengirim malaikat untuk menemaninya di dalam sumur serta memberikan petunjuk kepada Malik mengenai keberadaan Nabi yusuf. Peristiwa tersebut sesuai dengan salah satu ayat Al-Quran yang berbunyi "Itulah petunjuk Allah, yang dengannya Dia memberi petunjuk kepada siapa yang dikehendaki-Nya di antara hamba-hamba-Nya. Sesungguhnya jika manusia sama menyekutukan kepada Allah, maka niscaya lenyaplah manusia itu dari amalan yang sudah mereka kerjakan di dunia." (Q.S. Al-An'am, 6:88). Sehubungan dengan dengan penjelasan tersebut, Nata (2014:10) mengemukakan bahwa keyakinan atau kepercayaan terhadap adanya Tuhan merupakan tempat berlindung dan memohon pertolongan. Dengan demikian dapat disimpulkan bahwa keimanan seorang yang berwujud kepercayaan kepada Tuhan akan mengantarkan pada kebaikan, yaitu pertolongan dari sang pencipta.

\section{Ketaatan Manusia terhadap Tuhan}

Ketaatan diartikan sebagai kepatuhan, kesalehan dan kesetiaan. Menurut Anita (2015:3) ketaatan merupakan sikap disiplin atau taatnya perilaku terhadap suatu aturan yang telah ditetapkan. Ketaatan merupakan implementasi perilaku positif manusia. Wujud ketaatan manusia terhadap Tuhan dapat dilihat melalui ketaatan dalam menganut agama dengan menjalankan ajaranajaran agama di dalamnya sebagai wujud dari pengabdian manusia kepada Tuhan. Semakin taat seseorang dalam bidang agama, maka semakin positif sikap dan perilakunya dalam kehidupan. Ketaatan manusia terhadap Tuhan tidak hanya wajib dilakukan oleh orang beragama Islam. Akan tetapi seluruh agama telah mengajarkan wajibnya taat kepada Tuhan. Hal tersebut dapat dibuktikan dengan pendapat Harry dan Andreas (2015:96) yang mengemukakan bahwa ketaatan adalah kunci utama yang tidak bisa dipisahkan dalam hal mengikut Tuhan. Di dalam kitab Filipi 2:1-11, Paulus memberikan gambaran sosok Kristus yang luar biasa dalam hal ketaatan kepada Bapa. Paulus mengatakan bahwa dalam keadaan Kristus sebagai manusia, Ia telah merendahkan dirinya dan taat sampai mati di kayu salib. Hal tersebut sudah jelas diterangkan dalam Tafsiran Alkitab Masa Kini.

Perkara ketaatan manusia terhadap Allah sebagai Tuhan telah dicantumkan secara mendetail dalam Al-Quran dan Hadist. Salah satu contoh ayat Al-Quran yang menekankan ketaatan kepada Allah sebagai Tuhan adalah Q.S. An-Nisa (4:59), yaitu mewajibkan bagi orangorang yang beriman agar taat kepada Allah dan Rasul-Nya serta ulil amri di antara manusia. Atas dasar ayat tersebut, Kuntowijoyo (2017:17) kemudian membagi ketaatan menjadi tiga hal, yaitu humanisasi atau perintah kebaikan, liberasi atau mencegah kemunkaran, dan transendensi atau beriman kepada Tuhan. Dengan demikian, ketaatan manusia terhadap Tuhan dapat diartikan sebagai kepatuhan dalam meyakini dan menganut ajaran-ajaran agama sebagai bentuk dari pengabdian diri kepada Tuhan Yang Maha Esa. Ketaatan manusia terhadap Tuhan merupakan kecenderungan manusia kepada Tuhan dengan mewujudkan segala perintah Tuhan-Nya dan menjauhi segala larangannya. Penjelasan tersebut diperkuat dengan adanya pendapat dari Ramayulis (2016:113-114) yang menjelaskan bahwa ketaatan seorang manusia merupakan bentuk dari rasa syukur dan pengabdiannya kepada sang pencipta.

Dalam Naskah Yusuf juga telah dijelaskan bahwa Nabi Yusuf memiliki ketaatan yang kuat terhadap Allah SWT sebagai Tuhannya. Salah satu peristiwa yang mencerminkan Nabi Yusuf memiliki ketaatan yang kuat adalah ketika ia harus tetap berbohong demi patuh kepada ayahnya. 
Di dalam Serat Yusuf telah banyak dijabarkan wujud dari ketaatan seorang hamba terhadap Allah, berikut pemaparan lebih jelasnya.

\author{
Janji Allah dalam Pupuh III Kasmaran (PIIK) pada Bait ke-14 \\ Wontên wahyune Yang Widi / maring Nabi Dawud ika / sing sapa apaksa kabèh / \\ angulatana ing ring wang / pasti ningsun kapêndhag / lawan malih wong dèn têmu \\ / sun wèhi waspadeng tingal // \\ Terjemahan : \\ Ada wahyu berasal dari Tuhan (Allah) / kepada Nabi Daud / siapa yang \\ bersungguh-sungguh / mencari diri-Ku (Allah) / tentu akan menemukan / dan \\ apabila bisa bertemu / Akan kuberikan penglihatan yang tajam//
}

Pada bait ke-14 tersebut dijelaskan bahwa Allah telah berjanji kepada Nabi Daud. Janji merupakan ucapan yang menyatakan kesediaan dan kesanggupan untuk melakukan (seperti hendak memberi, datang, menolong, dan bertemu). Janji Allah terebut bukan hanya diberikan kepada Nabi Daud semata, akan tetapi diberikan juga kepada seluruh umat-Nya. Janji Allah tersebut telah tercantum dalam salah satu firman-Nya yang berbunyi "Jika dia (hamba) mendekat kepada-Ku (Allah) satu jengkal, maka Aku akan mendekat kepadanya satu hasta, jika dia mendekat kepada-Ku satu hasta, maka Aku akan mendekat kepadanya satu depa, dan jika dia mendatangi-Ku dengan berjalan, maka Aku akan mendatanginya dengan berlari." (Hadits Jami' At-Tirmidzi:3527). Firman dari Allah tersebut menjelaskan bahwa tidak ada yang perlu dicari lagi oleh manusia dalam kehidupan yang sifatnya sementara (duniawi). Karena manusia telah diwajibkan untuk mencari Allah dengan sungguh-sungguh dan Allah akan memberikan nikmat dan pertolongan kepada hamba-Nya.

Kesungguhan yang diupayakan oleh manusia untuk mencari ke-Esa-an Allah juga diartikan bahwa manusia telah siap untuk meninggalkan segala hal yang bersifat keduniawian. Sehubungan dengan penjelasan tersebut, Husna (2016:177) mengatakan bahwa manusia yang memiliki sifat keduaniawian cenderung dimotivasi oleh sifat egois. Hal tersebut dikarenakan dirinya lebih mementingkan diri sendiri daripada orang lain. Ketidaksiapan dalam meninggalkan dunia dianggap sebagai ekspresi dari sifat kepribadian individu materialistis. Sementara dengan kesiapan, Allah mencukupkan apa yang dibutuhkan manusia semasa di dunia. Karena sejatinya Allah akan memberikan apa yang kita butuhkan, bukan apa yang kita inginkan. Namun, seringkali manusia cepat putus asa dalam bersungguh-sungguh. Selaras dengan penjelasan janji Allah kepada manusia dalam agama Islam, janji Tuhan kepada umat-Nya juga telah ditetapkan dan dijelaskan dalam sebuah kitab suci. Salah satu kitab suci yang memperkuat perkara janji Tuhan kepada umatNya adalah kitab Agama Kristen Misi Dalam Perjanjian Lama. Isi dari kitab tersebut menerangkan bahwa nabi Yesaya membawa berita penghiburan kepada mereka (umat), Ia memberitahukan rencana keselamatan dengan menunjuk kepada keagungan Allah dan berjanji bahwa Allah akan mengampuni, membebaskan, memberikan pertolongan, dan memulangkan umat-Nya (Rasmalem, 2019:30).

Kejujuran Nabi Yusuf dalam Pupuh I Kasmaran ( $\left.\mathrm{P}^{\mathrm{I}} \mathrm{K}\right)$ pada Bait ke-34 Anglujiteng jêroneng ati / Bagendha Yusup kawuhan / apajaring sêwapnani / dadêya wong murtading rama / yèn ingsung tan awarta / kêna linyok awak ingsung / ingsung tan arsa linyoka //

Terjemahan :

Dirasakan di dalam hatinya / Baginda Yusuf sedang susah hatinya / kalau mimpinya ia katakan / ia mendurhakai pada ayahnya / kalau aku (Nabi Yusuf) tidak menceritakannya / maka aku akan berdusta / aku tidak ingin berdusta// 
Nilai moralitas berwujud kejujuran dimaknai mengakui, berbicara atau memberikan informasi sesuai dengan kenyataan yang ada (Albert, 2017:167). Dalam era disruptif ini, nilai kejujuran merupakan hal yang langka dan mahal. Pemikiran tersebut sesuai dengan penjelasan yang menjelaskan bahwa pada dasarnya nilai-nilai kejujuran sudah mulai punah (Putri, Dewantara, 2018:1). Maka daripada itu, hilangnya nilai kejujuran dapat menimbulkan ketidakpercayaan antara satu pribadi dengan pribadi yang lain. Terjadi krisis kepercayaan yang mengakibatkan munculnya jarak sosial dalam masyarakat. Nilai kejujuran dalam Naskah Yusuf tercermin pada sikap Nabi Yusuf yang tidak bisa berbohong walaupun dalam keadaan terdesak sekalipun. Kejujuran akan membawa manusia pada derajat yang lebih tinggi. Nilai kejujuran juga telah diterangkan dalam Q.S At-Taubah (199) yang berbunyi "Wahai orang-orang beriman, bertakwalah kepada Allah dan bersamalah kamu dengan orang yang benar (jujur)." Sehubungan dengan ayat dalam Al-Quran tersebut, nilai kejujuran diperkuat lagi oleh pemikiran Jhon White dalam Alkitab. Menurut White (2012:124-150) kejujuran yang dijelaskan oleh Alkitab bukan hanya sekedar tidak berbohong, namun kejujuran melibatkan keseluruhan cara hidup benar dan juga pola pemikiran yang patut sehingga menghasilkan manusia yang terpuji.

Dalam bait ke-34 tersebut dijelaskan bahwa Nabi Yaqub (ayah Nabi Yusuf) melarang dirinya untuk menceritakan mimpi yang dialaminya kepada orang lain, terutama pada saudarasaudaranya. Hal tersebut menempatkan Nabi Yusuf seperti halnya dua mata pisau. Jika dirinya jujur dengan mengatakan mimpi yang dialaminya, maka dia akan melanggar ucapan ayahnya. Namun jika dirinya tidak berkata jujur, maka dirinya sama saja berdusta. Manusia yang mnejunjung tinggi kejujuran pasti memiliki keimanan bahwa Allah selalu melihat apa yang telah dilakukan hamba-Nya. Ketika ia berkata dusta, maka akan muncul rasa tidak nyaman di hatinya. Ajaran tentang nilai kejujuran juga dicerminkan oleh macan yang termuat dalam bait ke-99 sampai 101 dan bait ke-105 sampai 108. Dalam bait ke-99 sampai 101 diceritakan bahwa macan takut mengatakan yang sejujurnya bahwa ia tidak membunuh Nabi Yusuf. Ia juga takut dianggap membuat fitnah dan mengadu domba Nabi Yaqub dengan anak-anaknya. Macan mengetahui jika ia berbohong, maka Allah akan akan memasukkannya di neraka.

\section{Selalu Bersyukur seperti Nabi Ya'qub termuat pada Pupuh I Kasmaran (P'K) pada Bait ke-29}

Lingira nabYa'kub malih / ayuwa tan wêruh sira / tuwan sih panggunggung Yang Manon / sukura kêna dênira / asih mulyaning pangeran / èstu suwapna nireku / mapan nabi sira tuwan //

Terjemahan :

Nabi Ya'qub lalu berkata kembali / jangan tiada enkau ketahui / Engkau telah diliputi kasih Tuhan (Allah) / penuh rasa syukurlah dirimu / atas kasih kemuliaan dari Tuhan (Allah) / sungguh mimpimu itu / dinobatkan engkau (Ya'qub) sebagai Nabi //

Bait tersebut berisi nasihat Nabi Ya'qub supaya selalu bersyukur atas pemberian Allah. Emmons dan Shelton (2014, p.36) mengatakan bahwa bersyukur merupakan sebuah komponen psikologis semacam rasa kagum, penuh rasa terimakasih serta penghargaan terhadap hidup. Sejalan dengan pemikiran tersebut, Ibnu Manzhur (dalam Fauzan, 2012:13) mengemukakan bahwa syukur adalah membalas kenikmatan (kebaikan orang lain) dengan ucapan, perbuatan, serta niat. Nasihat Nabi Yaqub tidak hanya sebatas bercerita akan tetapi juga ditujukan kepada semua manusia. Dengan pemberian Allah yang berupa kesehatan, rezeki dan rasa tenang, maka manusia diwajibkan untuk selalu bersyukur. Selaras dengan hal tersebut.

Bersyukur berarti menerima pemberian dan keadaan dengan hati yang lapang. Ketika manusia mampu bersyukur berarti ia mampu untuk tidak mengharap lebih apalagi membandingbandingkan dengan kehidupan orang lain. Karena sikap tersebut hanya akan menghabiskan waktu 
dan energi terhadap hal yang belum tentu menjadi miliknya. Harsena dan Holil (2018, p.701) mengatakan bahwa manusia yang mendapat kemuliaan berarti ia telah dikasihi oleh Allah, yang selalu senantiasa mengingat-Nya di dalam hidupnya. Penjelasan tersebut selaras dengan pendapat Fauzan (2012:15) yang mengatakan bahwa orang yang pandai bersyukur adalah orang yang mengakui nikmat Allah dan mengakui Allah sebagai pemberi, tunduk kepada-Nya, ridha terhadapNya, dan mempergunakan nikmat dalam segala hal yang Tuhan senangi. Oleh sebab itu, rasa syukur hendaknya disertai dengan ilmu dan amal yang didasari oleh ketundukan serta kecintaan sebagai manusia kepada Tuhan.

\section{Selalu Berbuat Kebaikan termuat pada Pupuh I Kasmaran ( $\left.\mathbf{P}^{\mathrm{I}} \mathbf{K}\right)$ pada Bait ke-36 \\ Ênêngêna wangseki / sabda rasul kang kocapa / ing wong sadêya ngêrusak mengko /lampahing kang tan yuktêya / tan pindah bahning ponang / anggêsêngi ning rêbek / mêngkana manah aniyaya // \\ Terjemahan : \\ Tinggalkanlah sebentar sanak saudara itu / Sang Rasul telah bersabda / manusia yang suka berbuat kerusakan / dan bertingkah tiada seharusnya / tiada beda seperti layaknya api / yang mana membakar habis / menjadikan hati teraniaya //}

Bait tersebut berisi sabda Rasul yang menerangkan bahwa manusia yang suka berbuat kerusakan atau memiliki perilaku tercela digambarkan sebagai api. Api tersebut akan merusak segala sesuatu yang berada di sekitarnya. Dengan dibuatnya perumpaan tersebut, pembaca diharapkan dapat menerima dan memahami makna tersirat dari sabda Rasul yang terdapat dalam Serat Yusuf. Sikap manusia yang tercela terjadi karena hatinya jauh dari kasih, ajaran dan cahaya Allah. Secara tidak langsung, manusia tersebut menjerumuskan dirinya sendiri dalam siksaan, baik siksaan di dunia berupa ketidaktenangan hati dan di akhirat berupa siksaan dari Allah.

Akhlak tercela merupakan tingkah laku atau perbuatan jahat yang merusak iman dan menjatuhkan martabat seseorang. Selaras dengan pernyataan tersebut, Az-Zuhaili (2014:301) menambahkan bahwa perbuatan tercela terbagi menjadi lima, yaitu ananiyah, gadab, hasad, gibah, dan namimah. Di zaman kini, banyak manusia larut dalam gelapnya kehidupan dan terlena karena materi dunia semata. Itu semua terjadi karena manusia melupakan bahkan meninggalkan ajaran-ajaran yang telah Allah muat dalam Al-Quran. Salah satu faktor utama kerusakan dalam diri manusia adalah godaan iblis. Diterangkan bahwa iblis selalu mencoba menghalang-halangi manusia dan menjauhkan manusia dari ajaran Allah.

\section{Segera Bertaubat termuat pada Pupuh I Kasmaran ( $\left.\mathbf{P}^{\mathrm{I}} \mathrm{K}\right)$ pada Bait ke-52}

Pada $\mathrm{P}^{\mathrm{I} K}$ bait ke-52 dalam Serat Yusuf berisi peringatan untuk manusia untuk menyegerakan taubat. Taubat diartikan sebagai salah satu bentuk positif dari religious coping untuk meminta pengampunan kepada Tuhan (Keshavarzi, dan Haque, 2013). Sehubungan dengan pengertian tersebut, Ghazali (2014:91-93) menambahkan bahwa syarat taubat terbagi menjadi empat, yaitu meninggalkan perbuatan dosa dengan dibarengi tekad hati yang kuat bahwa yang bersangkutan tidak akan mengulang dosa tersebut, menghentikan dan meninggalkan semua dosa yang telah dia lakukan (pada masa lalu) sebelum dia bertobat, dosa yang ditinggalkannya (sekarang) harus sepadan dengan dosa yang pernah dilakukannya, dan meninggalkan dosa harus karena mengagungkan Allah SWT.

Konsep taubat bukan hanya dilakukan dalam agama Islam, akan tetapi juga seluruh agama lainnya. Konsep taubat atau repentance sama-sama membahas mengenai tata cara pemerolehan pengampunan dari Tuhannya. Penjelasan tersebut didukung oleh pendapat dari Lindsay dan Eliade (2015:775) yang berbunyi often interpreted as a religious ceremony that brings one's behavior and attitude accompanied by feelings of sadness and regret for past violations. Artinya, taubat 
sering diartikan sebagai upacara keagamaan yang membawa tingkah laku dan sikap seseorang dengan disertai perasaan sedih dan penyesalan atas pelanggaran masa lampau. Bertaubat kepada Allah diawali dengan insyafnya seorang manusia dari kemaksiatan yang telah dilakukan. Allah akan menerima taubatnya apabila manusia tersebut benar-benar menyesal dan memohon ampunan kepada-Nya dengan kesungguhan hati. Mengakui kesalahan diri sendiri merupakan hal yang paling mudah namun akan terasa berat untuk dilakukan. Hal tersebut terjadi karena masih adanya keegoisan hati untuk mengakui perbuatan salah yang telah dilakukannya. Jika kita pelajari Naskah Yusuf lebih mendalam, sejatinya Nabi merupakan makhluk Allah yang selalu terjaga dari kesalahan dan kemaksiatan dalam kehidupannya. Nabi juga digolongkan sebaik-baiknya makhluk dan dijamin apa-apa yang akan atau telah dilakukan akan selalu mendapatkan pengampunan dari Allah. Secara tidak langsung, perilaku Nabi tersebut memberikan suatu gambaran pendidikan kepada umatnya dalam menjalankan kehidupan dunia. Menurut pendapat Ghazali (2014:96) taubat harus dilakukan secepatnya. Hal tersebut dikarenakan kemaksiatan yang dihubungkan dengan keimanan, maka gambaran yang dihasilkan bagaikan makanan basi yang membahayakan organ tubuh, makanan itu sama dengan bakteri bahkan virus yang merusak dengan cepat tanpa disadari.

\section{Kepasrahan Manusia terhadap Tuhan}

Kepasrahan berasal dari kata pasrah yang memiliki arti sadar akan keberadaan Tuhan dan menggantungkan dirinya kepada Tuhan setelah berusaha sekuat tenaga dalam kapasitasnya sebagai individu (Muthari, 2015:7). Pemikiran tersebut menunjukkan bahwa manusia yang beragama akan selalu berpegang padi tali Tuhan dalam kehidupannya. Tuhan dapat dijadikan perenungan yang dapat membawa kita dalam bentuk-bentuk keindahan dan kebenaran yang lebih tinggi atau hakiki. Manusia sadar bahwa Tuhan yang menentukan seluruh kehidupan manusia. Kepasrahan manusia kepada Tuhan karena dirinya tidak memiliki kekuatan sedikitpun tanpa bantuan-Nya. Kepasrahan manusia terhadap Tuhan merupakan salah satu kekuatan. Menurut Crapps (2014:12-13) konsep kepasrahan kepada Tuhan tidak dapat terlepas dari budaya religius manusia. Sesuai dengan pendapat Robert, kepasrahan terhadap Tuhan tidak terlepas dari nilai dalam Al-Quran. Menurut pandagan Islam, Tuhan merupakan satu-satunya penolong bagi manusia.

Menurut ajaran Islam maupun Kristiani, konsekuensi dari kepasrahan terhadap Tuhan dapat memberikan ketenangan jiwa atau hati manusia. Gagasan tersebut diperkuat oleh pemikiran Theo (2012:72) yang menyatakan bahwa sikap keagamaan seperti ibadah dan kepasrahan akan menumbuhkan harapan dan pandangan yang positif terhadap kehidupan manusia. Selain itu juga mengurangi rasa tertekan atau depresi dalam kejiwaan manusia. Dalam Naskah Yusuf telah dijelaskan bahwa Nabi Yusuf memiliki sikap tawakal atau kepasrahan terhadap Allah SWT sebagai Tuhannya. Salah satu peristiwa yang mencerminkan Nabi Yusuf memiliki sikap tawakal yang kuat adalah ketika dirinya dimasukkan ke dalam telaga oleh saudaranya. Di dalam Naskah Yusuf telah dijelaskan wujud dari kepasrahan manusia terhadap Allah, berikut pemaparannya.

\section{Kepasrahan Nabi Ya'qub terhadap Allah termuat dalam Pupuh I Kasmaran (P'K) pada Bait ke-45 dan 46}

Anêngakêna rumehin / sabdaning Yang kocapa / adhawuhing Ya 'kub gage / mulane sira tan asêrah/ sira datan pêrcaya / saking ing pangraksaningsun / kaliwat kasilib ira // Wus ngrasa Ya'kub niki / yen luput tumulya tubat / anêlangseng jêro dêriyani / kaluputaneng wêncana / karo enggala tubat / dening tan sêrah Hyang Agung / pujêr amèngêting anak //

Terjemahan :

Tinggalkanlah sebentar / dikisahkan Tuhan (Allah) telah bersabda / Dia berkata kepada Ya'qub / disebabkan kau tidak mau berserah diri / kau tidak percaya / atas penjagaanku terhadap Yusuf / kau kelewat pada lupa diri // Ya'qub telah merasa / 
jika dirinya salah lalu mneyegerakan taubat / menderita di dalam lubuk hatinya / telah salah dalam bertutur kata / hingga menyegerakan ia taubat / karena tidak berserah diri kepada Tuhan (Allah) / hanya selalu teringat akan anaknya //

Bait ke-45 dan 46 yang dimuat dalam $\mathrm{P}^{1} \mathrm{~K}$ menjelaskan Allah telah bersabda kepada Nabi Ya'qub bahwa ia harus percaya kepada Allah jika Allah akan selalu memeberikan penjagaan terhadap Nabi Yusuf. Selain itu, dari penggalan tembang diatas, dijelaskan bahwa Nabi Ya'qub segera melaksanakan tobat ketika ia lupa akan kehendak Allah. Hal tersebut dilakukan oleh Nabi Ya'qub karena ia merasa bersalah dan menderita sebab hanya mengingat anak-anaknya. Sikap pasrah atau tawakal terhadap Tuhan dijelaskan secara rinci dalam semua kitab suci dari agama masing-masing. Wajibnya memiliki sikap percaya dan pasrah terhadap Tuhan diperkuat oleh pemikiran Dethan (2018, p.177) yang menegaskan rasa percaya dan pasrah merupakan bagian dari keimanan manusia. Manusia harus percaya pada pertolongan-Nya ketika ia berpasrah setelah melakukan usaha. Dengan kata lain, Tuhan akan menolong setiap keadaan hamba-Nya.

\section{Kepasrahan Nabi Yusuf terhadap Allah termuat dalam Pupuh I Kasmaran (P'K) pada Bait ke-73.}

Kocape Yusup anênggih / tanibakêning têlaga / binuwangeng kêdhong nyang wong / lumêmpat sarwa tah sira / sedhakêp mêngkal dhadha / mênggah mirsah Nabi Yusup / sarwa angudud ambêkan //

Terjemahan :

Dikisahkan sang Nabi Yusuf / dijatuhkan ke dalam sebuah telaga / dilemparkan ke dalam jeram / maka melompatlah ia (Yusuf) sambil / bersedekap tangan memeluk dada / teguh dalam berserah diri Nabi Yusuf / sambil menarik napasnya //

Bait ke-73 yang dimuat dalam $\mathrm{P}^{1} \mathrm{~K}$ menjelaskan bahwa pada saat itu Nabi Yusuf dimasukkan ke dalam telaga oleh saudaranya sendiri. Ketika dilemparkan, Nabi Yusuf langsung mengingat Allah. Ia telah berusaha semampunya sebagai manusia, namun ketika usahanya tidak membuahkan hasil, nabi Yusuf berdoa dan tawakal kepada Allah. Nabi Yusuf yakin bahwa pertolongan Allah akan segera datang kepadanya. Perjalanan hidup Nabi Yusuf tentang ketawakalannya telah diceritakan secara rinci dalam Q.S. Yusuf (1-111). Dalam cerita tersebut terdapat Nabi Yusuf yang dibuang kemudian ditemukan oleh musafir dan selanjutnya dijual. Cerita tersebut berlanjut sampai ia harus terpisah dengan Nabi Ya'qub. Kuatnya Nabi Yusuf dalam menghadapi segala cobaan tersebut karena di dalam hatinya telah tertanam sikap tawakal yang kuat. Namun di era disruptif ini tidak sedikit manusia mengabaikan bahkan mengganggap isi kandungan Al-Qur'an berupa kisah para Nabi terdahulu hanya sebuah dongeng belaka tanpa ada maksud yang tersirat (Izzan, 2012:219).

Kedua data tersebut berisi ajaran untuk manusia agar memiliki sikap pasrah atau tawakal. Ketika dalam hati terdapat rasa ketakutan, khawatir, cemas dan selalu bergantung pada orang lain merupakan tanda-tanda bahwa manusia tersebut belum menyandarkan dirinya secara utuh kepada Tuhan. Sehubungan dengan hal tersebut, sikap pasrah bukan putus asa dan menyalahkan kehendak Tuhan. Akan tetapi, berpasrah atau tawakal merupakan salah satu cara manusia meminta pertolongan dan kemudahan dalam kehidupannya kepada sang Pencipta (Khalidi, Syam, 2017:432). Jika manusia menanamkan sikap tawakal dalam dirinya, ia akan senantiasa menerima kenyataan yang telah dikehendaki oleh Tuhan.

\section{Relevansi Nilai Moral Religiusitas terhadap Era Disruptif}

Era disruptif merupakan era dimana komunikasi dan teknologi semakin maju, informasi tidak lagi dibendung, sumber informasi tidak hanya diperoleh dari satu atau dua media saja, melaikan puluhan, ratusan, bahkan ribuan. Era disruptif dapat menjadi media pembawa informasi 
dan pengetahuan bagi manusia (Kristiawan, 2015:25). Di bagian awal dijelaskan bahwa perkembangan zaman di era disruptif memliki ruang yang luas bagi manusia untuk memenuhi hakhak kemanusiaan. Namun di era tersebut juga memungkinkan bergesernya nilai-nilai sosial masyarakat. Ruang yang digunakan untuk pemenuhan hak-hak kemanusiaan dapat melalui sharing of information yang sudah lama menjadi budaya modern ini. Dengan adanya sharing of information tersebut, masyarakat lebih cepat tahu dan paham akan persoalan kemanusiaan dan lebih cepat bergerak untuk ikut serta dalam upaya penegakan pemenuhan hak-hak kemanusiaan. Namun di sisi lainnya, peluang tergesernya tatanan nilai sosial juga perlu perhatian lebih. Menjadikan manusia sebagai tujuan utama dalam praktik internasional dapat dilakukan guna mencapai keutuhan tatanan sosial.

Sikap yang menjadikan manusia sebagai tujuan utama dalam praktik kehidupan merupakan wujud pengimplementasian nilai moral religiusitas. Nilai-nilai moral religiusitas yang terdapat di dalam Serat Yusuf sangat relevan terhadap manusia di era disruptif. Hal tersebut dikarenakan Serat Yusuf berisi ajaran untuk senantiasa menjunjung moral berbalut religi yang berhubungan dengan bab Ketuhanan. Ajaran moral religiusitas tersebut berupa keimanan, ketaatan, dan kepasrahan kepada Sang Pencipta. Ajaran-ajaran tersebut merupakan pedoman untuk manusia dalam menjalani kehidupan sebagai mahkluk-Nya. Isi Serat Yusuf menjadi sangat penting keberadaannya di era disruptif. Hal tersebut dikarenakan pandangan tentang agama dan Tuhan yang merupakan produk budaya harus diubah. Artinya, manusia harus sadar bahwa dirinya mampu mengurus dunia dengan kekuatan dan kekuasaan yang sudah dilimpahkan Tuhan kepadanya. Usaha untuk melibatkan Tuhan dalam kehidupan manusia justru akan menimbulkan kekisruhan. Pemikiran seperti itu disebut dengan sekularisasi.

Secara etimologi, kata sekularisasi berasal dari kata saeculum 'dunia,abad', sementara isasi diartikan sebagai imbuhan yang artinya proses menjadi. Maka daripada itu, sekularisasi artinya menjadikan sesuatu sebagai sekular (menjadikan sesuatu bersifat duniawi atau terlepas dari nilai serta aturan agama) (David, 2015:131). Dari pengertian tersebut dapat diketahui bahwa sekularasi berusaha mengubah pandangan hidup yang menempatkan Tuhan sebagai pusat kehidupan (teosentris). Sehingga yang akan menjadi pusat kehidupan berganti menjadi manusia itu sendiri (antroposentris). Oleh sebab itu, dalam era disruptif ini diperlukan nilai moral dan nilai religius yang kuat untuk membentengi diri dari jalan yang menyimpang.

Era disruptif tidak dapat dihindari dan akan terus berlangsung serta menuntut adanya adaptasi yang cepat dalam masyarakat. Untuk mengatasi permasalahan di era disrutif, penyadaran masyarakat adalah solusi terbaik (Clarke, Murphy, \& Lorenzoni, 2018:28). Dengan demikian, manusia harus benar-benar sadar pentingnya nilai moralitas dan nilai religiusitas yang terkandung dalam Serat Yusuf untuk diterapkan dalam kehidupan. Dengan kesadaran yang dimiliki manusia bahwa apapun yang akan dilakukan semasa di dunia pasti dimintai pertanggungjawaban di hari kiamat. Manusia juga harusnya sadar bahwa segala sesuatu yang dimiliki saat ini hanya sekedar titipan semata. Oleh sebab itu, tidaklah pantas jika ada seorang manusia yang menyombongkan diri dan hartanya. Keyakinan-keyakinan terhadap Tuhan dalam diri manusia akan menjadi pengontrol tingkah laku hidup di dalam dunia serta pengontrol tatanan nilai-nilai sosial di masyarakat. Ketika tatanan sosial dapat dikontrol, dampak dari era disruptif menjadi lebih sedikit dan tidak menjadi permasalahan yang berarti.

\section{SIMPULAN}

Nilai moral religiusitas dalam Serat Yusuf dapat diklasifikasikan menjadi tiga bentuk, yaitu keimanan manusia terhadap Tuhan, ketaatan manusia terhadap Tuhan dan kepasrahan manusia terhadap Tuhan. Ketiga bentuk nilai moral religiusitas tersebut digunakan pengarang untuk memberikan pandangan serta pegontrol tingkah laku manusia semasa hidup di dunia. Ajaranajaran nilai moral berbalut religi menjadikan Serat Yusuf dipandang sebagai salah satu serat yang wajib diteliti lebih mendalam. Nilai-nilai yang berhubungan dengan Ketuhanan sejatinya tidak 
akan pernah bisa lepas dari manusia. Selain itu, dengan pengamalan nilai moral religiusitas tidak akan menjadi permasalahan yang berarti dalam era disruptif sebagai hasil berkembangnya zaman. Penanaman ajaran moral berdasar agama mutlak adanya. Hal tersebut merupakan salah satu upaya dalam mempersiapkan individu bermoral dan sepiritual dalam arus perubahan zaman kini ke zaman selanjutnya.

Penelitian terhadap Serat Yusuf masih sangat terbatas. Di dalam Serat Yusuf, terdapat pupuh-pupuh lain yang belum dilakukan penelitian. Saran bagi peneliti selanjutnya yang ingin meneliti Serat Yusuf, diharapkan dapat mengkaji Naskah Serat Yusuf lebih komprehensif. Hal tersebut dimaksudkan agar fungsi dari Serat Yusuf sebagai media penyebaran ajaran agama Islam tidak hanya menjadi topik pembacaan semata. Banyak hal yang dapat digali baik dari pandangan masyarakat Jawa maupun Islam.

\section{DAFTAR PUSTAKA}

Albert, W. (2017) Kejujuran Dalam Pendidikan. Jurnal Innovatio, Vol. IX, No.1.

Al-Fauzan, A.B.S. (2012). Indahnya Bersyukur Bagaimana Meraihnya. Bandung: Marja.

Az-Zuhaili, W.(2014). Ensiklopedia Akhlak Muslim: Berakhlak dalam Bermasyarakat. Jakarta: Mizan Publika.

Basuki, A., Thohir, M. Abdullah, M., Muzakka, Yusuf, T. dan Rukiyah. (2004). Pengantar Filologi. Semarang: Fasindo Jurusan Sastra Indonesia Fakultas Sastra Universitas Diponegoro.

Bertens, K. (2011). Etika Cetakan Kesebelas. Jakarta: Gramedia Pustaka Utama.

Cholil, A. (2014). Dahsatnya Al-Quran. Jakarta: AMP Press.

Clarke, D., Murphy, C., \& Lorenzoni, I. (2018). Place Attachment, Disruption, And Transformative Adaptation. Journal of Environmental Psychology, 55, 81-89. https://doi.org/10.1016/j.jenvp.2017.12.006.

Crapps W. R. (2014). Perkembangan Kepribadian dan Keagamaan (terj. An introduction to Psychology of Religion. Macon, Georgia: Mercer University Press, 1986), Yogyakarta: Kanisius.

Crystall, D. (2015). The Cambridge Encyclopedia. Cambridge: Cambridge University Press.

Endraswara, S. (2018). Falsafah Hidup Jawa. Yogyakarta: Cakrawala.

Ghazali, (al). Minhajul Abidin, terj. oleh Abul Hiyadh. Surabaya: Mutiara Ilmu, 1995; dan edisi terj. oleh M. Rofiq. Yogyakarta: Diva Press, 2007; serta edisi terj. Oleh R. Abdullah bin Nuh. Jakarta: Mizan, 2014.

Harsena, D. S., \& Holil, M. (2018). Sikap Ngelmu pada Teks Wedharan Wewadining Bawana Paper presented at the INUSHARTS (International Young Scholars Symposium on Humanities and Arts) Depok.

Hidayat, O. S. (2015). Metode Pengembangan Moral dan Nilai-Nilai Agama.. Tangerang Selatan: Universitas Terbuka.

Izzan, A. dan Saehudin. (2012). Tafsir Pendidikan (Studi Ayat-Ayat Berdimensi Pendidikan). Tangerang Selatan: Pustaka Aufa Media.

Jalaluddin, (2016). Psikologi Agama. Jakarta: PT Raja Grafindo Persada.

KBBI, (2018). Kamus Besar Bahasa Indonesia (KBBI). [Online] Available at: https://kbbi.web.id/ [Diakses 20 April 2021].

Keshavarzi, H., \& Haque, A. (2013). Outlining a Psychotherapy Model for Enhancing Muslim Mental Health Within an Islamic Context. The International Journal for the Psychology of Religion.

Khalidi, M. W. A., \& Syam, H. M. (2017). Representasi Nilai-Nilai Moral dalam Lirik Lagu Doda Idi (Studi Semiotik terhadap Lirik Lagu Doda Idi dalam Album Nyawoung). Jurnal ilmiah $\begin{array}{llll}\text { mahasiswa } & \text { FISIP } & \text { 4nsyiah, }\end{array}$ http://www.jim.unsyiah.ac.id/FISIP/article/view/5522/2631. 
Kosim, N. dan Wahab, W. (2018). Konsepsi Makna Hari Kiamat Dalam Tafsir Al-Quran. Jawa Barat: Universitas Padjadjaran.

Kristiawan, M. (2015). Telaah Revolusi Mental dan Pendidikan Karakter Dalam Pembentukan Sumber Daya Manusia Indonesia Yang Pandai dan Berakhlak Mulia. Jurnal Ta'did. Volume 18, Hal. 13-25.

Kuntowijoyo. (2017). "Paradigma Islam: Interpretasi Untuk Aksi". Yogyakarta: Tiara Wacana.

Kurnia, Y. (2015). Pengembangan Kemampuan Nilai-Nilai Agama dan Moral di TK. Bandung: PPPPTK TK dan PLB.

Lindsay, J. 2015. Encyclopedia of Religion, ed. ${ }^{\text {2nd }}$ (USA: Macmillan Reference).

Muhammad, M. (2016). Inilah Jalan Yang Lurus. Jakarta: PT Gramedia.

Mulyani, H. (2009). Teori Pengkajian Filologi. Diktat Mata Kuliah Filologi Jawa pada Semester IV. Tidak Diterbitkan. Jurusan Pendidikan Bahasa Daerah. Fakultas Bahasa dan Seni Universitas Negeri Yogyakarta.

Muthari, A.H.W. (2015). "Sastra Profetik, Nilai-Nilai dan Relevansinya" Prosiding Seminar Internasional Bahasa, Sastra dan Pembelajarannya Pengembangan Nilai-Nilai Profetik dalam Kehidupan Berbangsa melalui Bahasa, Sastra, dan Pembelajarannya. Diselenggarakan Program Studi Pendidikan Bahasa dan Sastra Indonesia FKIP UMM, Malang 17-18 November 2015.

Nata, A. (2014). Pemikiran Pendidikan Islam dan Barat. Jakarta: PT. Raja Grafindo Persada.

Nurgiyantoro, B. (2013). Teori Pengkajian Fiksi. Yogyakarta: Gajah Mada University Press.

Ohoitimur, J. (2018). Disrupsi: Tantangan Perkembangan Ilmu Pengetahuan dan Peluang Bagi Lembaga Pendidikan Tinggi Resepons, 23(2), 143-166. http://ejournal.atmajaya.ac.id/index.php/response/article/view/553/216.

Pinandito, S.(2011). Husnuzan dan Sabar Kunci Sukses Meraih Kebahagiaan Hidup Kiat-Kiat Praktis Berfikir Positif Menyiasati Persoalan Hidup. Jakarta: Penerbit PT Elex Media Komputindo.

Pora, S. (2014). Tinjauan Filosofis Kearifan Lokal Sastra Lisan Ternate. Jurnal Uniera, 3(1), 112121. Retrieved from https://journal.uniera.ac.id/jview/69.

Putri, K. D., \& Dewantara, A. (2018). Mulai Punahnya Nilai Kejujuran Dikaji Dengan Buku Diskursus Pancasila Dewasa Ini. https://doi.org/10.31227/osf.io/6m38z.

Ramayulis. (2016). Pengantar Ilmu Jiwa Agama. Jakarta: Kalam Mulia.

Roli Abdul Rohman, (2009). Menjaga Akidah dan Akhlak. Solo: PT Tiga Serangkai Pustaka Mandiri.

Sari, L.M.F. (2013). Tingkat Religiusitas Dengan Kecemasan Menghadapi Menopause. Jurnal Online Psikologi Vol. 01 No. 02. Fakultas Psikologi Universitas Muhammadiyah Malang. Malang.

Sudardi, B. (2001). Naskah, Teks, dan Metode Penelitian Filologi. Surakarta: Penerbit Sastra Indonesia, Fakultas Sastra Universitas Sebelas Maret.

Sudarman, H. dan Andreas, D. (2015). Doktrin Inkarnasi Kristus. Yogyakarta: ANDI.

Sugiyono. (2015). Metode Penelitian Kombinasi (Mix Methods). Bandung: Alfabeta.

Sugiyono. (2017). Metode Penelitian Kuantitatif, Kualitatif, dan R\&D. Bandung: Alfabeta.

Thoyyibah, N. (2016). Nilai-Nilai Pendidikan Keimanan dan Ketaqwaan (Studi Analisis Novel Pesantren Impian Karya Asma Nadia). (Sarjana Skripsi), Universitas Islam Negeri Walisongo, Semarang. Retrieved from http://eprints.walisongo.ac.id/id/epri nt/6023.

Ulfah, S. (2011). Naskah Primbon: Suntingan Teks Disertasi Analisis Diksi Dialek Madura. Skripsi. Surabaya: Fakultas Ilmu Budaya, Universitas Airlangga.

White, J. (2012). Kejujuran Moral Dan Hati Nurani. Jakarta: BPK Gunung Mulia. 